\title{
True Cost Accounting of Food Using Farm Level Metrics: A New Framework
}

\author{
Harpinder Sandhu ${ }^{1, *(\mathbb{D})}$, Adele Jones ${ }^{2}$ and Patrick Holden ${ }^{2}$ \\ 1 Centre for Markets, Values and Inclusion, UniSA STEM, University of South Australia, \\ Adelaide, SA 5062, Australia \\ 2 Sustainable Food Trust, Bristol BS34TQ, UK; adele@sustainablefoodtrust.org (A.J.); \\ patrick@sustainablefoodtrust.org (P.H.) \\ * Correspondence: harpinder.sandhu@unisa.edu.au
}

Citation: Sandhu, H.; Jones, A.; Holden, P. True Cost Accounting of Food Using Farm Level Metrics: A New Framework. Sustainability 2021, 13, 5710. https://doi.org/10.3390/ su13105710

Academic Editor: Riccardo Testa

Received: 29 March 2021

Accepted: 13 May 2021

Published: 19 May 2021

Publisher's Note: MDPI stays neutral with regard to jurisdictional claims in published maps and institutional affiliations.

Copyright: (c) 2021 by the authors. Licensee MDPI, Basel, Switzerland. This article is an open access article distributed under the terms and conditions of the Creative Commons Attribution (CC BY) license (https:// creativecommons.org/licenses/by/ $4.0 /)$.

\begin{abstract}
The application of true cost accounting (TCA) at farm level requires a common framework and metric for measuring, capturing and valuing sustainability. We propose such a framework and farm metric that build on the four capitals—natural, social, human and produced-that are essential for sustainability. The framework is developed by reviewing the scientific and technical literature on various approaches and tools that have been used to measure farm sustainability. We use quantifiable aspects of sustainability in the farm metrics. The farm sustainability metrics comprise four capitals with 11 categories and 33 indicators. These indicators can be assessed using bio-physical assessment, descriptive or quantitative methods. Once this information is compiled for a farm, then some of the categories can be monetised to reflect all the costs and benefits of using state-of-the-art TCA. There is a need to establish benchmarks and standards for each of the four types of capitals and indicators for the comparison of food systems. We believe the use of this comprehensive framework and farm metrics will help to correct several deficiencies of the current food system. We conclude by highlighting the benefits and limitations in the use of farm metrics. Measuring all positive and negative externalities at farm level can shift global food systems towards sustainability.
\end{abstract}

Keywords: farm sustainability; TCA; natural capital; social capital; human capital

\section{Introduction}

Global food systems are able to produce sufficient food to meet the calorific demand for the current human population. However, about 690 million people do not have access to food, and 2 billion do not have regular access to nutritious food [1]. There is growing awareness that the global agriculture and food systems will not be able to meet the targets set up by the United Nations' Sustainable Development Goals (SDGs) in meeting the demand for safe, healthy and nutritious food by more than 9 billion people by 2030 [2,3]. It is also realised worldwide that the food systems that include production, processing, distribution and consumption have massive impacts on the environment and climate [4]. For example, a third of global greenhouse gas emission comes from food systems, they cover $38 \%$ of the Earth's terrestrial surface, consume more than $70 \%$ of global freshwater, and one third of all food is not eaten but wasted [2,5-7]. In order to meet the global targets of healthy and safe food for all, and by maintaining environmental sustainability, there is a need to address food systems more holistically. This has potential to address global climate change and will also help achieve the SDGs related to food. In order to address food systems more holistically, there is need to measure, capture and value the sustainability of food systems [2]. Here, we provide a new framework to measure, capture and value sustainability at farm level as a proof of concept for the application of true cost accounting (TCA) of food. In this study, we use a farm as the smallest functional unit of the global food system to demonstrate the application of TCA. 
The term 'food systems', "encompasses the entire range of actors and their interlinked value-adding activities involved in the production, processing, distribution, consumption, and disposal of food products that originate from agriculture, forestry or fisheries, and parts of the broader economic, societal, and natural environments in which they are embedded" [8] (p. 1).

Current agricultural and food systems have been designed to maximise per hectare productivity by using a large amount of agrochemicals and energy inputs. They aim to maximise profits. However, such production systems (i) do not value the contribution of ecosystem services, (ii) often overlook social capital in agriculture, and (iii) fail to address the negative impact of intensive practices on ecological health. Such systems may increase production and profits, but they negatively impact social and natural capital as compared to some of the sustainable alternatives $[9,10]$. Such high input-output-based food production systems are also supported by the current economic and policy environment.

Therefore, there is need to understand, assess and monetise all costs and benefits of different types of food production systems. This information then can be used to develop more sustainable food systems by appropriate policy response.

\section{Background}

There has been several initiatives and frameworks that have been developed at the global, national, and landscape scale to recognise and value the benefits that biodiversity provides to people, by including natural capital into national accounting process. These are summarised in Table 1.

Table 1. An overview of approaches and tools to measure sustainability.

\begin{tabular}{|c|c|c|}
\hline $\begin{array}{l}\text { Initiatives/ } \\
\text { Assessments }\end{array}$ & Millennium Ecosystem Assessment [11] & $\begin{array}{l}\text { Recognition of the Importance of Ecosystem Services } \\
\text { in Providing Life Support Functions of the Planet }\end{array}$ \\
\hline & $\begin{array}{l}\text { The Economics of Ecosystem Services and } \\
\text { Biodiversity (TEEB) [12] }\end{array}$ & Value of ecosystems and biodiversity in global economy. \\
\hline & $\begin{array}{l}\text { The Economics of Ecosystem Services and } \\
\text { Biodiversity in Agriculture and Food systems } \\
\text { (TEEBAgriFood) [2] }\end{array}$ & $\begin{array}{l}\text { Value of nature, social capital, human skills and } \\
\text { knowledge, public health in agriculture and food } \\
\text { systems. }\end{array}$ \\
\hline & IPBES [13] & Global assessment of nature's contribution to people. \\
\hline & $\begin{array}{l}\text { System of Environmental-Economic } \\
\text { Accounting [14] }\end{array}$ & $\begin{array}{l}\text { Accounting for environmental pollution, land use } \\
\text { change, anthropogenic emissions in national accounts. }\end{array}$ \\
\hline & The Dasgupta Review [15] & Economics of biodiversity. \\
\hline \multirow[t]{3}{*}{ Tools } & Ecological Footprint [16] & $\begin{array}{l}\text { The quantity of natural resources required to support } \\
\text { people or an economy. }\end{array}$ \\
\hline & Life Cycle Analysis [17] & $\begin{array}{l}\text { It evaluates the life cycle of a product by measuring the } \\
\text { environmental impact throughout its value chain stages, } \\
\text { including final disposal and recycling. It also includes } \\
\text { measuring impacts such as the extraction of resources } \\
\text { required to produce that product. }\end{array}$ \\
\hline & Life Cycle Costing [18] & $\begin{array}{l}\text { It includes all stages of the value chain. It includes } \\
\text { production, processing, manufacturing, distribution, } \\
\text { consumption and recycling. This approach is focused on } \\
\text { the use of resources and reflects both internal and } \\
\text { external costs. Internal costs include the cost of } \\
\text { materials, energy, labour, capital, etc., whereas external } \\
\text { costs include the environmental impact of the processes, } \\
\text { the cost of pollution, the cost of health problems and the } \\
\text { social cost. }\end{array}$ \\
\hline
\end{tabular}


Table 1. Cont.

Initiatives/

Assessments
Millennium Ecosystem Assessment [11]

Activity-Based Costing $[19,20]$

Material Flow Costing [21] [22-24]

Full Cost Accounting [25]
Recognition of the Importance of Ecosystem Services in Providing Life Support Functions of the Planet

It includes the costs of each activity that is required to produce a product. This approach helps to divide environmental costs (by products), the composition of the environmental costs and strengthen the environmental cost management of the operations.

It measures the flows and stocks of materials in manufacturing. It produces accounts in both physical and monetary units. Material cost accounting helps organisations to improve their business efficiency and reduce environmental impacts.

A system that explicitly includes all direct and indirect costs and benefits of a transaction. Most of the tools in EMA measures the direct costs of pollution but full cost accounting includes indirect costs as well. These indirect costs and benefits are incurred by the direct beneficiaries or any third parties involved in a transaction. It includes conventional business costs, environment costs and social costs of product or services.

An accounting method to assess the social, economic and environmental performance of an organisation. It includes both financial and non-financial performance and allows organisations to look at their business from five perspectives; economic, social, internal business, learning and growth and environmental.

It is defined as an approach to understand the positive and negative impacts of food systems on the natural environment, society, and the economy.

Out of the above approaches, the Economics of Ecosystem and Biodiversity in Agriculture and Food systems (TEEBAgriFood) provides a comprehensive approach to analyse costs and benefits of global farming and food systems [2]. There are several tools that have been developed to assess the impacts of food systems, as summarised in Table 1. However, there is lack of a single farm-based evaluation framework and metric that can measure, capture and demonstrate all costs and benefits across all four capitals-produced, social, human and natural.

Here, we propose a new framework to measure, capture and value sustainability using farm metrics as an application of the TCA of a food system.

\section{Economic Foundations of TCA}

TCA approaches are trans-disciplinary in nature as they are derived from the principles of ecological economics [27]. TCA is based on the principles that our economic system is embedded in the natural environment. TCA is often described as a critical tool or a mechanism to understand the impacts and dependencies, both positive and negative, of food systems on people, their health, natural environment and economic system [28]. The main aim of TCA in food systems is to create just and fair food systems that meet the current need for food and also meet the future need by promoting the sustainable use of resources. TCA analysis can be applied to assess agri-products, compare different diets, farming systems, farm and food policies, and national accounts or corporate balance sheets $[2,3]$. The TCA approach does not necessarily mean monetising all the costs and benefits associated with food systems. However, it has evolved over a period of time by improving the environmental-accounting approaches and can be used to monetise several externalities. 


\section{Farm Sustainability Framework}

In order to apply TCA in food systems, there is a need to first develop a comprehensive farm-based sustainability framework and metric. We use a bottom-up approach to develop this new framework. The bottom-up approach is farm-centric and is based on threetechnical, geographic, and social—indicators. The environmental, economic, and social sustainability of food systems depend on these three fundamental indicators [29]. It is based on the premise that if all the costs and benefits of a farm are known or can be calculated in terms of biophysical, descriptive, or monetary units, then we will be able to form a better understanding of the farm sustainability. This information then can feed into the local economy, supply chains, retails, agribusiness, supermarkets and eventually into national accounts. This can be scaled up to form a global understanding of all costs and benefits of the remaining food value chain-processing, manufacturing, transport, consumption. Incentives for generating public goods and services or penalties for degrading them can then flow from top-down towards supporting farm sustainability.

Therefore, we have chosen a farm as the smallest unit in the global food systems to apply TCA in food systems. There are 570 million farms around the world that form the basic functional unit in the global food system.

We reviewed the scientific and technical literature to identify various tools that are available to assess sustainability at farm level [30,31]. There are about 100 tools that are currently available to assess various aspects of agricultural sustainability [30,31]. They differ in the use of scope, methods and frameworks. Some of the commonly used methods are LCA used by the Cool Farm Tool (CFT) [32], multi criteria analysis used by Response Inducing Sustainability Evaluation (RISE) [33] and Public Goods (PG) [34] tools, triple bottom line (TBL_by PG Tool and Sustainability Assessment of Food and Agriculture Systems (SAFA) [35], ecosystem services assessment by the healthy farm index, and Integrated Evaluation of Ecosystem Services and Tradeoffs (InVEST) [36]. These tools capture key aspects of social, environmental and economic dimensions of farming [31]. These tools are able to capture and assess bio-physical aspects of farming and food more comprehensively but fall short on monetising any costs and benefits. In addition, these tools are developed to be used as a top-down approach to assess farm sustainability by industry or government for specific purposes. These purposes could vary from incentivising farmers to produce more production or nutrition or improving one or more aspects of environmental indicators. Therefore, each time, farmers would use a different tool for a different purpose. Therefore, the farm metric is being developed to overcome some of the shortcomings of the existing tools. It goes beyond capturing bio-physical aspects and provides the outputs in a format that can be monetised using TCA to reflect key costs and benefits of the food production system in the farm accounts. Farmers and farm managers often have to supply farm data in different formats using multiple tools for the purpose of certification (for organic), direct payments (to receive farm payment from the government) and agri-environment schemes. The farm metrics developed here respond to the need for convergence between various tools and data collection methods. The SAFA framework and TEEBAgriFood frameworks are used to develop this converged farm metric to reflect all relevant aspects of farm sustainability. The reporting format is based on SAFA as it allows farmers and farm managers to easily comprehend the results [35]. Other commonly used tools such as CFT, PG, RISE, etc. use lengthy reports to interpret the results [31].

Based on our review, we identified 11 broad categories that are aligned to natural, social, human and produced capital as suggested by the TEEBAgriFood study. These are summarised in Table 2. 
Table 2. A new framework and metrics to assess farm sustainability.

\begin{tabular}{|c|c|c|c|c|c|c|c|}
\hline Capital & Weights & Category & Indicator & Description & Sub-Indicator & Sub-Weights & $\begin{array}{l}\text { Method for } \\
\text { Assessment }\end{array}$ \\
\hline \multirow{9}{*}{$\begin{array}{l}\text { Natural } \\
\text { capital }\end{array}$} & 0.25 & & $\begin{array}{l}\text { Soil organic } \\
\text { matter }\end{array}$ & $\begin{array}{l}\text { Organic matter } \\
\text { in soil that is } \\
\text { critical for } \\
\text { maintaining soil } \\
\text { structure, } \\
\text { biodiversity and } \\
\text { function such as } \\
\text { storing nutrients } \\
\text { and } \\
\text { accumulating } \\
\text { carbon }\end{array}$ & $\begin{array}{c}\text { Soil organic } \\
\text { carbon }\end{array}$ & 2.08 & $\begin{array}{c}\text { Bio-physical } \\
\text { assessment }\end{array}$ \\
\hline & & Soil & Biodiversity & $\begin{array}{l}\text { Micro and macro } \\
\text { diversity in soil } \\
\text { that is essential } \\
\text { to perform soil } \\
\text { functions }\end{array}$ & $\begin{array}{l}\text { Faunal } \\
\text { diversity, } \\
\text { macro and } \\
\text { microbial }\end{array}$ & 2.08 & $\begin{array}{c}\text { Bio-physical } \\
\text { assessment }\end{array}$ \\
\hline & & & Structure & $\begin{array}{l}\text { Physical and } \\
\text { chemical } \\
\text { properties of soil }\end{array}$ & $\begin{array}{c}\text { Available } \\
\text { water capacity } \\
(\mathrm{mm}) / \text { tillage } \\
\text { type/land use } \\
\text { classification }\end{array}$ & 2.08 & $\begin{array}{c}\text { Bio-physical } \\
\text { assessment }\end{array}$ \\
\hline & & \multirow{3}{*}{$\begin{array}{l}\text { Air and } \\
\text { climate }\end{array}$} & $\begin{array}{l}\text { Emissions by } \\
\text { source }\end{array}$ & $\begin{array}{l}\text { Greenhouse gas } \\
\text { emissions from } \\
\text { the use of } \\
\text { machinery, } \\
\text { energy, livestock } \\
\text { and all other } \\
\text { farm-related } \\
\text { activities }\end{array}$ & $\begin{array}{c}\mathrm{CO}_{2} \mathrm{e} \\
\text { (tonnes/acre) }\end{array}$ & 2.08 & $\begin{array}{c}\text { Bio-physical } \\
\text { assessment }\end{array}$ \\
\hline & & & $\begin{array}{c}\text { Carbon } \\
\text { sequestration }\end{array}$ & $\begin{array}{l}\text { Potential to } \\
\text { sequester carbon } \\
\text { in soil, above } \\
\text { ground and } \\
\text { below ground } \\
\text { vegetation }\end{array}$ & $\begin{array}{c}\mathrm{CO}_{2} \mathrm{e} \\
\text { (tonnes/acre) }\end{array}$ & 2.08 & $\begin{array}{c}\text { Bio-physical } \\
\text { assessment }\end{array}$ \\
\hline & & & $\begin{array}{l}\text { Nutrient } \\
\text { balance }\end{array}$ & $\begin{array}{l}\text { Emissions from } \\
\text { nutrient use to } \\
\text { be estimated as } \\
\text { carbon dioxide } \\
\text { equivalents }\end{array}$ & $\begin{array}{c}\mathrm{CO}_{2} \mathrm{e} \\
\text { (tonnes/acre) }\end{array}$ & 2.08 & $\begin{array}{l}\text { Bio-physical } \\
\text { assessment }\end{array}$ \\
\hline & & \multirow{3}{*}{ Biodiversity } & Agriculture & $\begin{array}{c}\text { Crop } \\
\text { biodiversity on } \\
\text { farm }\end{array}$ & Crop diversity & 2.08 & $\begin{array}{c}\text { Bio-physical } \\
\text { assessment }\end{array}$ \\
\hline & & & Natural & $\begin{array}{c}\text { Animal } \\
\text { biodiversity on } \\
\text { farm }\end{array}$ & $\begin{array}{c}\text { Diversity/rare } \\
\text { breeds/local } \\
\text { breeds }\end{array}$ & 2.08 & $\begin{array}{c}\text { Bio-physical } \\
\text { assessment }\end{array}$ \\
\hline & & & Landscape & $\begin{array}{c}\text { Diversity of } \\
\text { natural elements } \\
\text { on the landscape }\end{array}$ & $\begin{array}{l}\text { Conservation } \\
\text { area/wetlands / } \\
\text { hedgerows }\end{array}$ & 2.08 & $\begin{array}{c}\text { Bio-physical } \\
\text { assessment }\end{array}$ \\
\hline
\end{tabular}


Table 2. Cont.

\begin{tabular}{|c|c|c|c|c|c|c|c|}
\hline Capital & Weights & Category & Indicator & Description & Sub-Indicator & Sub-Weights & $\begin{array}{l}\text { Method for } \\
\text { Assessment }\end{array}$ \\
\hline & & \multirow{3}{*}{ Water } & Source & $\begin{array}{l}\text { Sustainable } \\
\text { source of water }\end{array}$ & $\begin{array}{l}\text { Groundwater/ } \\
\text { surface wa- } \\
\text { ter/rainwater }\end{array}$ & 2.08 & $\begin{array}{l}\text { Bio-physical } \\
\text { assessment }\end{array}$ \\
\hline & & & Quality & $\begin{array}{l}\text { Biological, } \\
\text { physical and } \\
\text { chemical } \\
\text { properties of } \\
\text { water }\end{array}$ & $\begin{array}{c}\% \text { nutrients in } \\
\text { water }\end{array}$ & 2.08 & $\begin{array}{c}\text { Bio-physical } \\
\text { assessment }\end{array}$ \\
\hline & & & Sedimentation & $\begin{array}{l}\text { Catchment } \\
\text { management }\end{array}$ & $\begin{array}{c}\text { Protection } \\
\text { mea- } \\
\text { sure/dams }\end{array}$ & 2.08 & $\begin{array}{c}\text { Bio-physical } \\
\text { assessment }\end{array}$ \\
\hline \multirow{14}{*}{$\begin{array}{l}\text { Produced } \\
\text { capital }\end{array}$} & 0.25 & \multirow{3}{*}{$\begin{array}{l}\text { Energy and } \\
\text { resource use }\end{array}$} & $\begin{array}{c}\text { Energy } \\
\text { usage/mix }\end{array}$ & $\begin{array}{c}\text { Source of energy } \\
\text { use on farm }\end{array}$ & $\begin{array}{l}\text { Renewable/non- } \\
\text { renewable }\end{array}$ & 1.67 & $\begin{array}{l}\text { Bio-physical } \\
\text { assessment }\end{array}$ \\
\hline & & & $\begin{array}{l}\text { Energy self- } \\
\text { sufficiency }\end{array}$ & $\begin{array}{c}\text { Energy } \\
\text { generation on } \\
\text { farm }\end{array}$ & $\begin{array}{l}\text { Wind/biomass / } \\
\text { solar }\end{array}$ & 1.67 & $\begin{array}{c}\text { Bio-physical } \\
\text { assessment }\end{array}$ \\
\hline & & & $\begin{array}{c}\text { Waste/recycled } \\
\text { material }\end{array}$ & $\begin{array}{l}\text { Recycled } \\
\text { material use }\end{array}$ & Usage/recycling & 1.67 & $\begin{array}{l}\text { Bio-physical } \\
\text { assessment }\end{array}$ \\
\hline & & \multirow{3}{*}{$\begin{array}{l}\text { Plant and } \\
\text { crop health }\end{array}$} & $\begin{array}{c}\text { Pest and } \\
\text { disease } \\
\text { management }\end{array}$ & $\begin{array}{l}\text { Type of } \\
\text { management } \\
\text { regime }\end{array}$ & $\begin{array}{c}\text { Organic/ } \\
\text { agrochemicals }\end{array}$ & 1.67 & $\begin{array}{c}\text { Bio-physical } \\
\text { assessment }\end{array}$ \\
\hline & & & $\begin{array}{l}\text { Crops grown } \\
\text { and rotation }\end{array}$ & $\begin{array}{l}\text { Crop type and } \\
\text { rotations }\end{array}$ & $\begin{array}{c}\text { Crop- } \\
\text { legume- } \\
\text { crop/crop- } \\
\text { crop/crop- } \\
\text { pasture }\end{array}$ & 1.67 & $\begin{array}{c}\text { Bio-physical } \\
\text { assessment }\end{array}$ \\
\hline & & & $\begin{array}{l}\text { Nutritional } \\
\text { quality }\end{array}$ & $\begin{array}{l}\text { Quality, safety of } \\
\text { produce }\end{array}$ & $\begin{array}{l}\text { Nutritional } \\
\text { food }\end{array}$ & 1.67 & $\begin{array}{l}\text { Bio-physical } \\
\text { assessment }\end{array}$ \\
\hline & & \multirow{3}{*}{$\begin{array}{c}\text { Livestock } \\
\text { management }\end{array}$} & $\begin{array}{c}\text { Management } \\
\text { system }\end{array}$ & $\begin{array}{l}\text { Management } \\
\text { regime for } \\
\text { livestock }\end{array}$ & $\begin{array}{c}\text { Mixed, } \\
\text { intensive, } \\
\text { organic, etc. }\end{array}$ & 1.67 & $\begin{array}{l}\text { Bio-physical } \\
\text { assessment }\end{array}$ \\
\hline & & & $\begin{array}{l}\text { Nutrition } \\
\text { and input } \\
\text { efficiency }\end{array}$ & $\begin{array}{l}\text { Animal feed } \\
\text { source }\end{array}$ & Grazing/feed & 1.67 & $\begin{array}{c}\text { Bio-physical } \\
\text { assessment }\end{array}$ \\
\hline & & & $\begin{array}{l}\text { Diversity, } \\
\text { health and } \\
\text { welfare }\end{array}$ & Animal welfare & $\begin{array}{c}\text { Open } \\
\text { days/indoor }\end{array}$ & 1.67 & $\begin{array}{c}\text { Bio-physical } \\
\text { assessment }\end{array}$ \\
\hline & & \multirow{3}{*}{ Productivity } & $\begin{array}{l}\text { Physical } \\
\text { output }\end{array}$ & $\begin{array}{c}\text { Physical output } \\
\text { of farm }\end{array}$ & Quantity & 1.67 & $\begin{array}{c}\text { Bio-physical } \\
\text { assessment }\end{array}$ \\
\hline & & & $\begin{array}{l}\text { Financial } \\
\text { output }\end{array}$ & Net returns & Profits & 1.67 & $\begin{array}{l}\text { Monetary } \\
\text { units }\end{array}$ \\
\hline & & & $\begin{array}{c}\text { True cost } \\
\text { balance sheet }\end{array}$ & $\begin{array}{l}\text { Adjusted profits } \\
\text { after accounting } \\
\text { for all } \\
\text { externalities }\end{array}$ & $\begin{array}{l}\text { Costs and } \\
\text { benefits }\end{array}$ & 1.67 & $\begin{array}{l}\text { Monetary } \\
\text { units }\end{array}$ \\
\hline & & \multirow[t]{2}{*}{$\begin{array}{c}\text { Nutrient } \\
\text { management }\end{array}$} & $\begin{array}{c}\text { Nutrient } \\
\text { balance sheet }\end{array}$ & $\begin{array}{c}\text { Status of } \\
\text { nutrients in soil } \\
\text { and plants }\end{array}$ & $\begin{array}{l}\text { Soil/plant } \\
\text { nutrients }\end{array}$ & 1.67 & $\begin{array}{l}\text { Bio-physical } \\
\text { assessment }\end{array}$ \\
\hline & & & $\begin{array}{c}\text { Management } \\
\text { efficiency }\end{array}$ & $\begin{array}{l}\text { Resource use } \\
\text { efficiency }\end{array}$ & $\begin{array}{l}\text { Application } \\
\text { methods }\end{array}$ & 1.67 & $\begin{array}{l}\text { Bio-physical } \\
\text { assessment }\end{array}$ \\
\hline
\end{tabular}


Table 2. Cont.

\begin{tabular}{|c|c|c|c|c|c|c|c|}
\hline Capital & Weights & Category & Indicator & Description & Sub-Indicator & Sub-Weights & $\begin{array}{l}\text { Method for } \\
\text { Assessment }\end{array}$ \\
\hline & & & Inputs/outputs & $\begin{array}{l}\text { Balance in inputs } \\
\text { and outputs }\end{array}$ & Balance & 1.67 & $\begin{array}{l}\text { Bio-physical } \\
\text { assessment }\end{array}$ \\
\hline \multirow{3}{*}{$\begin{array}{l}\text { Social } \\
\text { capital }\end{array}$} & 0.25 & \multirow{3}{*}{ Social capital } & Health & $\begin{array}{l}\text { Perceived health } \\
\text { impacts on } \\
\text { community }\end{array}$ & $\begin{array}{l}\text { Community } \\
\text { health }\end{array}$ & 8.33 & $\begin{array}{l}\text { Quantitative, } \\
\text { Descriptive }\end{array}$ \\
\hline & & & $\begin{array}{l}\text { Community } \\
\text { engagement }\end{array}$ & $\begin{array}{l}\text { Farm networks } \\
\text { and participation } \\
\text { in local farming } \\
\text { community }\end{array}$ & Networks & 8.33 & $\begin{array}{l}\text { Quantitative, } \\
\text { Descriptive }\end{array}$ \\
\hline & & & Education & $\begin{array}{l}\text { Participation of } \\
\text { farm in science } \\
\text { and education }\end{array}$ & $\begin{array}{c}\text { Science, } \\
\text { research } \\
\text { participation }\end{array}$ & 8.33 & $\begin{array}{l}\text { Quantitative, } \\
\text { Descriptive }\end{array}$ \\
\hline \multirow{3}{*}{$\begin{array}{l}\text { Human } \\
\text { capital }\end{array}$} & 0.25 & \multirow{3}{*}{$\begin{array}{l}\text { Human } \\
\text { capital }\end{array}$} & $\begin{array}{l}\text { Health of } \\
\text { workers }\end{array}$ & $\begin{array}{l}\text { Health impacts } \\
\text { of farmers and } \\
\text { farm workers }\end{array}$ & Welfare & 8.33 & $\begin{array}{l}\text { Quantitative, } \\
\text { Descriptive }\end{array}$ \\
\hline & & & $\begin{array}{c}\text { Skills and } \\
\text { knowledge of } \\
\text { farm workers }\end{array}$ & $\begin{array}{c}\text { Professional } \\
\text { qualifications of } \\
\text { farm workers }\end{array}$ & $\begin{array}{l}\text { Technical or } \\
\text { professional } \\
\text { training }\end{array}$ & 8.33 & $\begin{array}{l}\text { Quantitative, } \\
\text { Descriptive }\end{array}$ \\
\hline & & & Employment & $\begin{array}{l}\text { Fair wages, } \\
\text { benefits of farm } \\
\text { employees }\end{array}$ & $\begin{array}{c}\text { Wages, } \\
\text { recreation } \\
\text { leave, benefits }\end{array}$ & 8.33 & $\begin{array}{l}\text { Quantitative, } \\
\text { Descriptive }\end{array}$ \\
\hline
\end{tabular}

The farm sustainability metrics comprise four capitals with 11 categories and 33 indicators [31]. These indicators can be assessed using bio-physical assessment, descriptive or quantitative methods. Quantitative methods are used to establish equal weights for each of the four types of capitals. Sub-weights are equally divided within each capital for various indicators. Once this information is compiled for a farm, then some of the categories can be monetised to reflect all costs and benefits while others can be described to represent the level of farm sustainability. Farm metrics describe four capitals as stocks accumulated over time and form the foundation of a functional farm. Flows of these capitals can be described in the form of ecosystem services for natural capital as positive impacts or benefits, agricultural inputs and output for produced capital as benefits, and any residual flows such as pollution and greenhouse gas emissions to capture negative impacts. Each of the four capitals and corresponding indicators are described below and summarised in Table 2.

\subsection{Produced Capital}

Produced capital includes agricultural inputs and outputs, including financial capital, and can be measured by using farm accounting standards by using definitions from the System of National Account. The concept of produced capital in agriculture and food systems is based on the TEEBAgriFood report [2,37]. It includes energy and resource use, plant and crop health, livestock management, farm productivity and nutrient management. Farm metrics include six indicators: energy and resource use, plant and crop health, livestock management, productivity, and nutrient management.

\subsection{Natural Capital}

Natural resources on a farm such as air, water, soil, biodiversity form the natural capital associated with food production. Natural resources can be measured by using the System of Environmental-Economic Accounting [14]. Flows of natural capital include ecosystem services. Residual flows include emissions, water and soil pollution, etc. 


\subsection{Social Capital}

Social capital in food systems include various networks of farmers, producers, market networks, community health, etc. that enable growers to respond as a collective to become more effective [38]. Social capital is based on trust, common rules, and norms and can be measured by assessing these inter-connections [39]. In farm metrics, it includes community health, engagement and education.

\subsection{Human Capital}

Human capital in food systems includes the health of farmers, farm workers, factory workers, processors, and their knowledge, skills and motivation. It also includes opportunities for gainful employment. It is based on the premise that food systems benefit from investments in people's skills and their health [40,41].

\section{How Does It Work?}

The farm sustainability framework provides a comprehensive assessment of a farm to develop better understating of the food systems. As summarised in Table 2, we assume that all four categories carry equal weights and there is a market incentive to maintain or enhance natural, social and human capitals alongside produced capital (Figure 1). Within each of these four capitals, weights are equally distributed for various indicators to reflect a comprehensive sustainability score. These weights should be held constant while discussing the incentive schemes with the decision makers, who could be market, consumers, government, etc. There is a need to first generate a benchmark for each of the indicators and capital so that different farms can be assessed to receive public or private benefits. For example, to assess natural capital/soil, three indicators can be tested, as shown in Table 3. Soil organic matter, biodiversity and structure have equal weights. A further final score can be assigned based on the bio-physical assessment of these three indicators per farm or site. Similarly, other categories can be worked out to generate a final score per farm that can be compared with neighbouring or other farms to receive market or policy incentives if they perform above the benchmark. The benchmark could be established by review of the scientific literature and in conjunction with primary biophysical assessment of natural resources in various agri-eco regions. Policy and market both need to work together to establish benchmarks for these categories for different type of farms and regions through spatial and temporal assessments.

Table 3. Application of farm metrics as an example of soil as natural capital.

\begin{tabular}{|c|c|c|c|c|c|c|c|}
\hline $\begin{array}{l}\text { Natural } \\
\text { Capital }\end{array}$ & Indicators & Description/Unit & Weights & $\begin{array}{l}\text { Value for } \\
\text { the Site }\end{array}$ & $\begin{array}{l}\text { Range in } \\
\text { Literature }\end{array}$ & $\begin{array}{l}\text { Extremely Low (1)/Low } \\
\text { (2)/Medium (3)/High } \\
\text { (4)/Very High (5) }\end{array}$ & $\begin{array}{l}\text { Final Score } \\
\text { (Column } 4 \times \\
\text { Column 7) }\end{array}$ \\
\hline 1 & 2 & 3 & 4 & 5 & 6 & 7 & 8 \\
\hline \multirow[t]{4}{*}{ Soil } & Health & $\begin{array}{l}\text { Soil organic } \\
\text { carbon }(\%)\end{array}$ & 0.33 & 3.96 & $1.5-12 \%$ & 3 & 0.99 \\
\hline & Biodiversity & $\begin{array}{c}\text { Earthworm } \\
\text { numbers } \\
\text { (number } / \mathrm{m}^{2} \text { ) }\end{array}$ & 0.33 & 28 & $\begin{array}{c}62-432 \\
\text { (number } / \mathrm{m}^{2} \text { ) }\end{array}$ & 1 & 0.33 \\
\hline & Structure & $\begin{array}{c}\text { Available } \\
\text { water capacity } \\
(\mathrm{mm}) / \text { tillage/land } \\
\text { use } \\
\text { classification }\end{array}$ & 0.33 & $\begin{array}{l}241 \mathrm{~mm} / \mathrm{no}^{-} \\
\text {till/pasture }\end{array}$ & $\begin{array}{c}100-375 \\
\mathrm{~mm} / \text { till, } \\
\text { no-till/land } \\
\text { use }\end{array}$ & 4 & 1.32 \\
\hline & & & & & & & $2.64 / 5$ \\
\hline
\end{tabular}




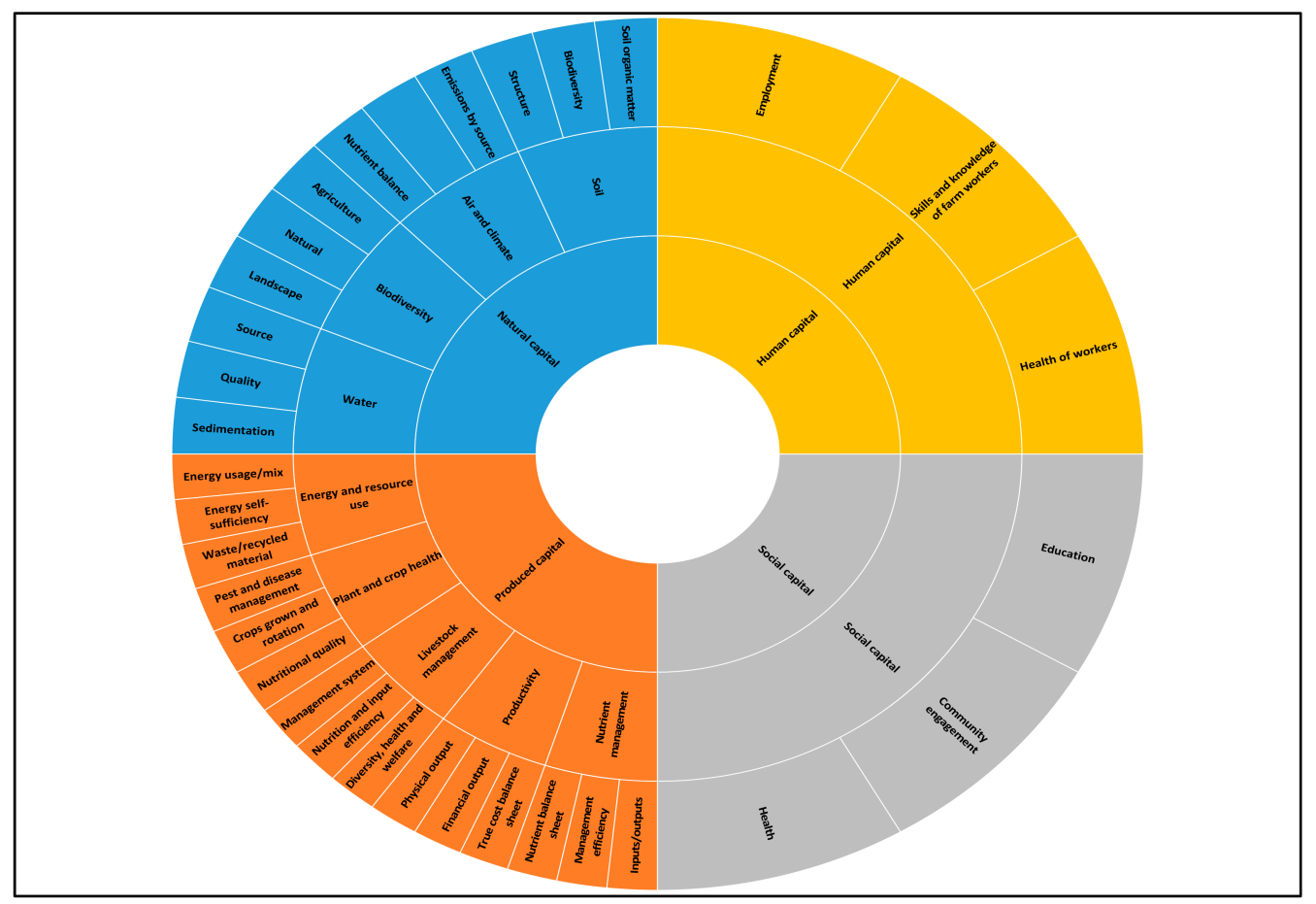

Figure 1. Farm metrics showing all four capitals, categories and indicators with equal weights to assess sustainability.

\section{From Farm Metrics to TCA}

Some of these indicators can then be used to aggregate all costs and benefits per farm [40]. TCA does not always involve monetised value but can be a descriptive or quantitative account of various categories in four capitals [10]. This will show if the overall farm performance has a positive or negative impact in all four capitals.

We anticipate that with the adoption of this novel, universal, and harmonised framework, farm sustainability will improve and also policy support from market and public policy can be better channelised to support better farm practices. While the metrics applied at farm scale is a bottom-up approach and can feed into global food systems, the incentives are top-down and need to reach out to farm from local or national food policy.

Sustainable agriculture and food systems can be developed by identifying and reducing all externalities by using this farm sustainability framework. This can be then used by national policy to incentivise agricultural practices that are less detrimental to the environment and human health and to penalise those that have high impacts.

The major output of applying this framework is to reveal the value of social and environmental benefits of sustainable food production along with any social and environmental costs of different food production systems. The agriculture and food industry will be able to see all hidden costs associated with the food production throughout the value chain and take necessary action to monitor and reduce them. The intended outcome is that farmers, farm managers, consumers and retailers can make better decisions on the basis of these economic values regarding their food production and consumption choices [27]. This information can then help producers to optimise benefits and minimise negative externalities; once the values are known, retailers can use this information in marketing sustainably grown produce by informing consumers about how (and how much) they minimise impacts on the environment and natural resources, and consumers can make better informed decision for themselves in making food choices [27].

The proposed framework is a comprehensive and up to date approach that can be used from the farm scale to the national policy level. However, there are several limitations and challenges in the use of this framework. One of the key challenges is data source and 
data collection. A process to streamline data collection is required with some uniform standards at local, regional and global scale. The farm sustainability framework and metric can be useful for producers, supermarkets, agribusinesses and governments. However, there are challenges in scoping each study based on its target audience. If farmers want to use it to correct their detrimental farming practices, then the scope is limited to the farm scale. In contrast, if a supermarket wants to raise awareness of the food that they sell, they need to have wider scope for applying this framework.

Currently, some market provides incentives to organic food with premium prices that are paid by consumers. Beside this there are no such incentives at farm, market or national agricultural policies to apply TCA and to understand impacts.

Consumers are not aware of all the impacts of food systems. However, there is increase in number of consumers who demand full disclosure in how food is produced. TCA can help them to understand these impacts and then support food products that are less damaging. However, there is need to raise awareness amongst consumers about the utility of TCA as a comprehensive tool $[10,27]$.

A lack of policy at national and global level also means there is no existing national or international accounting framework to advance the use and implementation of TCA through the value chain of each agriculture and food product.

\section{Conclusions}

We have developed a farm sustainability metric comprising four capitals-natural, produced, social and human-with an aim to apply TCA to food systems. This will help to identify the hidden costs of food production systems. TCA is being perceived as an approach as well as a tool to reveal hidden social and environmental costs of food systems. We have provided an application of TCA to farm level to develop this new framework. We also highlight that the application of this framework is challenging as it requires multi-dimensional data on environmental, social and health indicators, which may limit its use. Moreover, there is no current benchmark to compare sustainability across several farms or farming systems. We speculate that the widespread use of this metric will help users, researchers and practitioners to generate sufficient outputs to establish benchmarks. The farm sustainability framework proposed here is based on a comprehensive systems approach and builds on the existing environmental cost accounting framework and extends its scope to include social, human and health impacts in addition to environmental impacts in order to develop more sustainable agriculture and food systems. Some of the challenges and shortcomings in earlier tools, approaches, frameworks are addressed in the development of this metric [30,31,40]. The development of this framework is a first step in advancing the methodology to analyse farms to better understand and improve them. The further development of international standards followed by policy response through appropriate market incentives and national agriculture policies will help in the adoption of TCA applications more widely. This has the potential to assist the global community with operating agriculture and food systems within the planetary boundaries and advancing the wellbeing of farming communities around the world. Recognising and measuring all positive and negative externalities is not an end but a beginning towards more equitable and sustainable food systems.

Author Contributions: Conceptualization, H.S., A.J., P.H.; methodology, H.S., A.J., P.H.; software, H.S., A.J., P.H.; validation, H.S., A.J., P.H.; formal analysis, H.S., A.J., P.H.; investigation, H.S., A.J., P.H.; resources, H.S., A.J., P.H.; data curation, H.S.; writing—original draft preparation, H.S., A.J., P.H.; writing—review and editing, H.S., A.J., P.H.; visualization, H.S.; supervision, H.S., A.J., P.H.; project administration, H.S., A.J., P.H.; funding acquisition, H.S., A.J., P.H. All authors have read and agreed to the published version of the manuscript.

Funding: This research received no external funding.

Institutional Review Board Statement: Not applicable.

Informed Consent Statement: Not applicable. 
Data Availability Statement: All the data used in the study are provided in tables in the manuscript.

Conflicts of Interest: The authors declare no conflict of interest.

\section{References}

1. FAO; IFAD; UNICEF; WFP; WHO. The State of Food Security and Nutrition in the World. Transforming Food Systems for Affordable Healthy Diets; FAO: Rome, Italy, 2020. [CrossRef]

2. TEEB. The Economics of Ecosystems and Biodiversity. TEEB for Agriculture $\mathcal{E}$ Food: Scientific and Economic Foundations United Nations Environment, Geneva. 2018. Available online: http://teebweb.org/agrifood/scientific-and-economic-foundations-report/ (accessed on 10 January 2021).

3. Sandhu, H.; Müller, A.; Sukhdev, P.; Merrigan, K.; Tenkouano, A.; Kumar, P.; Hussain, S.; Zhang, W.; Pengue, W.; Gemmill-Herren, B.; et al. The future of agriculture and food: Evaluating the holistic costs and benefits. Anthr. Rev. 2019, 6, 270-278. [CrossRef]

4. IPCC. Intergovernmental Panel on Climate Change. Summary for Policymakers. In Climate Change and Land: An IPCC Special Report on Climate Change, Desertification, Land Degradation, Sustainable Land Management, Food Security, and Greenhouse Gas Fluxes in Terrestrial Ecosystems; IPCC: Geneva, Switzerland, 2019.

5. Herrero, M.; Thornton, P.K.; Mason-D'Croz, D.; Palmer, J.; Benton, T.G.; Bodirsky, B.L.; Bogard, J.R.; Hall, A.; Lee, B.; Nyborg, K.; et al. Food systems are responsible for a third of global anthropogenic GHG emissions. Nat. Food 2021. [CrossRef]

6. Ramankutty, N.; Evan, A.T.; Monfreda, C.; Foley, J.A. Farming the planet: 1. Geographic distribution of global agricultural lands in the year 2000. Glob. Biogeochem. Cycles 2008. [CrossRef]

7. FAO. Water for Sustainable Food and Agriculture: A Report Produced for the G20 Presidency of Germany; FAO Food and Agriculture Organization of the United Nations: Rome, Italy, 2007.

8. FAO. Sustainable Food Systems: Concept and Framework; FAO: Rome, Italy, 2018. Available online: http://www.fao.org/3/ca207 9en/CA2079EN.pdf (accessed on 10 January 2021).

9. Fitzpatrick, I.; Young, R. The Hidden Cost of UK Food. Sustainable Food Trust. 2017. Available online: http:// sustainablefoodtrust.org/wp-content/uploads/2013/04/HCOF-Report-online-version-1.pdf (accessed on 10 January 2021).

10. Gemmill-Herren, B.; Baker, L.E.; Daniels, P.A. (Eds.) True Cost Accounting for Food; Routledge: London, UK, 2021.

11. MEA. Millennium Ecosystem Assessment Synthesis Report; Island Press: Washington, DC, USA, 2005.

12. Sukhdev, P.; Wittmer, H.; Miller, D. The Economics of Ecosystems and biodiversity (TEEB): Challenges and Responses. In Nature in the Balance: The Economics of Biodiversity; Helm, D., Hepburn, C., Eds.; Oxford University Press: Oxford, UK, 2014.

13. Díaz, S.; Demissew, S.; Carabias, J.; Joly, C.; Lonsdale, M.; Ash, N.; Larigauderie, A.; Adhikari, J.R.; Arico, S.; Báldi, A.; et al. The IPBES Conceptual Framework-Connecting nature and people. Curr. Opin. Environ. Sustain. 2015, 14, 1-6. [CrossRef]

14. United Nations. System of Environmental-Economic Accounting 2012-Central Framework. United Nations, European Union, Food and Agriculture Organization of the United Nations, International Monetary Fund, Organization for Economic Co-operation and Development, The World Bank. New York. 2014. Available online: https://unstats.un.org/unsd/envaccounting/seearev/ seea_cf_final_en.pdf (accessed on 10 January 2021).

15. Dasgupta, P. The Economics of Biodiversity: The Dasgupta Review. Abridged Version; HM Treasury: London, UK, 2021.

16. Wackernagel, M.; Onisto, L.; Bello, P.; Linares, A.C.; Falfán, I.S.; García, J.M.; Guerrero, A.I.; Guerrero, M.G. National natural capital accounting with the ecological footprint concept. Ecol. Econ. 1999, 29, 375-390. [CrossRef]

17. EPA. Life Cycle Assessment: Principles and Practice. National Risk Management Research Laboratory Office of Research and Development; U.S. Environmental Protection Agency Cincinnati: Washington, DC, USA, 2006.

18. Howes, R. Environmental Cost Accounting: An Introduction and Practical Guide; The Chartered Institute of Management Accountants: London, UK, 2002.

19. Almeida, A.; Cunha, J. The implementation of an Activity-Based Costing (ABC) system in a manufacturing company. Procedia Manuf. 2017, 13, 932-939. [CrossRef]

20. Hoozee, S.; Hansen, S.C. A Comparison of Activity-Based Costing and Time-Driven Activity-Based Costing. J. Manag. Account. Res. 2018, 30, 143-167. [CrossRef]

21. Christ, K.L.; Burritt, R. Material flow cost accounting: A review and agenda for future research. J. Clean. Prod. 2014, 108, 1378-1389. [CrossRef]

22. Bebbington., J.; Gray, R.; Hibbitt, C.; Kirk, E. Full Cost Accounting: An Agenda for Action Certified Accountants Educational Trust; Certified Accountants Educational Trust: London, UK, 2001.

23. Elkington, J. Cannibals with Forks: The Triple Bottom Line of 21st Century Business; Capstone: Oxford, UK, 1999.

24. Jasinski, D.; Meredith, J.O.; Kirwan, K. A comprehensive review of full cost accounting methods and their applicability to the automotive industry. J. Clean. Prod. 2015, 108, 1123-1139. [CrossRef]

25. Al-Zwyalif, I.M. Using a balanced scorecard approach to measure environmental performance: A proposed model. Int. J. Econ. Financ. 2017, 9, 118-126. [CrossRef]

26. Lord, S. Valuing the Impact of Food: Towards Practical and Comparable Monetary Valuation of Food System Impacts; FoodSIVI: Oxford, UK, 2020.

27. Sandhu, H.; Regan, C.; Perveen, S.; Patel, V. Methods and Frameworks: The Tools to Assess Externalities. In True Cost Accounting for Food Balancing the Scale; Gemmill-Herren, B., Baker, L.E., Daniels, P.A., Eds.; Routledge: London, UK, 2021. 
28. Aspenson, A. "True" Costs for Food System Reform: An Overview of True Cost Accounting Literature and Initiatives; John Hopkins University: Baltimore, MD, USA, 2020. Available online: https:/ / clf.jhsph.edu/publications/true-costs-food-system-reformoverview-true-cost-accounting-literature-and-initiatives (accessed on 10 January 2021).

29. Sandhu, H. Bottom-Up Transformation of Agriculture and Food Systems. Sustainability 2021, 13, 2171. [CrossRef]

30. de Olde, E.M.; Oudshoorn, F.W.; Sørensen, C.A.G.; Bokkers, E.A.M.; de Boerc, I.J.M. Assessing sustainability at farm-level: Lessons learned from a comparison of tools in practice. Ecol. Indic. 2016, 66, 391-404. [CrossRef]

31. Sustainable Food Trust. Sustainability Assessment: The Case for Convergence; Sustainable Food Trust: Bristol, UK, 2017.

32. Cool Farm Alliance. The Cool Farm Tool. 2021. Available online: https:/ / coolfarmtool.org (accessed on 10 April 2021).

33. Hani, F.; Braga, F.; Stampfli, A.; Keller, T.; Fischer, M.; Porsche, H. RISE, a tool for holistic sustainability assessment at the farm level. Int. Food Agribus. Manag. Rev. 2003, 6, 78-90.

34. Gerrard, C.; Smith, L.G.; Pearce, B.; Padel, S.; Hitchings, R.; Measures, M. Public Goods and Farming, Farming for Food and Water Security, 10. Sustainable Agriculture Reviews, No. 8380; Springer: Berlin/Heidelberg, Germany, 2012; pp. 1-22.

35. FAO. Sustainability Assessment of Food and Agriculture Systems (SAFA): Guidelines, Version 3.0; Food and Agricultural Organization of the United Nations: Rome, Italy, 2013.

36. Natural Capital Project. Integrated Valuation of Ecosystem Services and Tradeoffs (InVEST). 2021. Available online: https: / / naturalcapitalproject.stanford.edu/software/invest (accessed on 10 April 2021).

37. UNU-IHDP; UNEP. Inclusive Wealth Report 2014. Measuring Progress toward Sustainability; Cambridge University Press: Cambridge, UK, 2014.

38. Putnam, R. The prosperous community: Social capital and public life. Am. Prospect 1993, 13, 35-42.

39. Pretty, J. Social capital and the collective management of resources. Science 2003, 302, 1912-1914. [CrossRef] [PubMed]

40. Sandhu, H.; Scialabba, N.E.; Warner, C.; Behzadnejad, F.; Keohane, K.; Houston, R.; Fujiwara, D. Holistic costs and benefits of corn production systems in Minnesota, USA: An application of TEEB AgriFood evaluation framework. Nat. Sci. Rep. 2020, $3922,1-12$.

41. Sweetland, S.R. Human Capital Theory: Foundations of a Field of Inquiry. Rev. Educ. Res. 1996, 66, 341-359. [CrossRef] 